\title{
Leadership Styles and Organizational Commitment with Mediation of Organizational Citizenship Behavior among Bahraini Managers
}

\author{
Mohamed Abdulaziz Zainuddin \\ Management Section, School of Distance Education \\ Universiti Sains Malaysia \\ Muhammad Hasmi Abu Hassan Asaari \\ Management Section, School of Distance Education \\ Universiti Sains Malaysia
}

\begin{abstract}
This study explores the role of organizational citizenship behavior as a mediating variable to the relationship between leadership styles and organizational commitment among Bahraini managers. Organizational citizenship behavior was in debate regards it is positive and negative consequences through the literature, most of the studies support the conclusion of organizational commitment that leads to organizational citizenship behavior, other studies support the opposite. However, the mediating relationship of organizational citizenship behaviors between leadership styles and organizational commitment is not developed by previous studies. Therefore, the use of the mediating variable gives more insight into the relationship between the dependent and independent variables and contributes to the clarity of conclusions. This study found that leadership presents a positive significant relationship with organizational commitment and organizational citizenship behavior, and organizational citizenship behavior positively and significantly affects organizational commitment and partially mediates the relationship between the two variables.
\end{abstract}

Keywords: Leadership, Organizational Commitment, Organizational Citizenship Behavior.

\section{Introduction}

Leadership behaviors were found to be positively linked with high-performance ratings, overall satisfaction and commitment, better objective performance, and satisfaction with supervisor (Graen et al., 1982; Vecchio \& Godbel, 1984; Duchon et al., 1986; Nystrom, 1990; Liden et al., 1993). Therefore, organizational citizenship behavior may be related to those tasks that are not part of job performance, but they are highly required by the organization (Schnake, 1991). Previous studies have driven the relation model between leadership and organizational citizenship behavior by considering trust, job satisfaction personal identification, motivation, goal commitment, work engagement, efficacy, and procedural justice as mediators (Kim, 2012), as well as studies asserted that the organizational citizenship behavior practice leads and cause the organization commitment. Taking into consideration the undeniable relationship between leadership and organizational commitment as well as organizational citizenship behavior, there are also studies by Zayas-Ortiz, Rosario, Marquez, and Gurneiro (2015) that emphasized the relationship between organizational citizenship with organizational commitment. According to Aydoğan (2010), it is found that employees who developed organizational and/or professional commitment are more likely to perform organizational citizenship behavior compared to the ones that did not and that employees will be committed to their organizations because of the opportunities they are offered, and this commitment becomes organizational citizenship behavior with the time which contributes to the organization itself (Bolat \& Bolat, 2008). Those studies agree with the conclusion of Mena (2015) the generally accepted view in the study of organizational behavior that organizational citizenship behavior considered the causal effect of organizational commitment, and that most of the studies are supporting that relationship between organizational commitment and organizational citizenship behavior, and that organizational citizenship behavior is antecedents of organizational commitment (Mathieu \&Zajac, 1990; Shore \& Wayne, 1993; Podsakoff and MacKenzie, 1997;

Tepper, 2004; Mena, 2015; Rauf, 2016; Traiyotee et al, 2019). However, Mena (2015) added that besides that most of the studies support the relationship between organizational commitment and organizational citizenship behavior, some studies support the opposite of organizational citizenship behavior leading to organizational commitment, and that was in line with the study of Rauf (2016). Further, Mena (2015) added that a study by Tepper et al. (2004) found that organizational citizenship behavior does affect the attitudes of fellow employees positively and consequently enhances the organizational loyalty and commitment among organization members. 
Revising all these significances in the organization's success and competitive advantages acquiring, increase the motivation for identifying a model that can link these variables together in one model that can describe the relationships among them. There is very little research available from the literature that examines the links between leadership behavior and employee's satisfaction and organizational commitment (Mosadeghard \& Ferdosi, 2013), even those studies are conducted or based on western countries (Mosadeghard \& Ferdosi, 2013; Jogulu\& Wood, 2008). However, studies that investigate job satisfaction and/or organizational commitment ignore the analysis of leadership behavior.

\section{Research Context}

\subsection{Relationship between Leadership and Organizational Commitment}

According to Mowday et al, (1982), leadership has been considered a determinant organizational factor of organizational commitment. Previous studies revealed that leadership does impact the organization's performance and effectiveness in different ways, and therefore leadership has been a source of debates and studies by different researchers. According to Horner (1997), different theories exist to define the leadership role and relationship to organizational effectiveness, including Fred Fiedler's theory of leadership contingency model theory, and the vertical dyad linkage theory which is called the leader-member exchange theory (Graen, 1976).To examine the effect that leadership would have or impact organizational commitment in any organization we need to examine the different leadership theories. According to Bolden et al. (2003), there is an evolving series of schools of thought starting from the Great Man and trait theories to the transformational leadership theories, which are considered early theories that tend to focus on the characteristics and behaviors of successful leaderships. The later theories emphasize the consideration of the role of followers and the contextual nature of the leadership.

Previous studies confirm that leadership styles and organizational commitment have a strong positive relationship and impact on organizational commitment (Ismail et al., 2011; Tremblay, 2010; Lo et al., 2009;Erkutlu, 2008; Limsila\& Ogunlana, 2008; Lee, 2005; McGuire \& Kennerly, 2006; Chen, 2002; Arnold et al., 2001).

\subsection{Relationship between Leadership and Organizational Citizenship Behavior}

According to Veličkovska (2017), leaders who take care of the interpersonal relationship at work and the satisfaction of employees will find the chance to develop organizational citizenship behavior within the organization. Previous studies revealed that leadership behavior and organizational citizenship behavior have a positive relationship and link with high-performance ratings, overall satisfaction and commitment, better objective performance, and satisfaction with supervisor (Graen et al., 1982; Vecchio \& Godbel, 1984; Duchon et al., 1986; Nystrom, 1990; Liden et al., 1993; Podsakoff et al., 2000). Therefore, organizational citizenship behavior may be related to those tasks that are not part of job performance, but they are highly required by the organization (Schnake, 1991). Another study also demonstrates a positive impact of supportive leadership on the deployment of organizational citizenship behavior by subordinates (LePine et al., 2002) and the development of organizational citizenship behavior norms and practices in groups (Ehrhart \& Naumann, 2004), Organ et al. (2006) found in an empirical study that all researchers observed the association between leadership behaviors and organizational citizenship behavior.

\subsection{Relationship between Organizational Citizenship Behavior and Organizational Commitment}

In the study of organizational citizenship behavior and its relationship to organizational commitment, many of the researchers and scholars found that employees who developed organizational and/or professional commitment are more likely to perform organizational citizenship behavior compared to the ones that did not (Aydoğan, 2010) and that employees will be committed to their organizations because of the opportunities they are offered, and this commitment becomes organizational citizenship behavior during the time which contributes to the organization itself (Bolat \& Bolat, 2008). Therefore, there is a significant relationship between organizational citizenship behavior and organizational commitment as most the studies present (Bogler\&Somech, 2004; Feather \&Rauter, 2004; Nguni et al., 2006; Bolat\&Bolat, 2008) while some studies did not conclude such a relationship between an organizational commitment (Tansky, 1993; Mercan, 2006). However, researchers concluded different impacts, while studies confirm that organizational commitment impact or positively linked to organizational citizenship behavior and therefore considered as its predictor (Meyer and Allen, 1990; Ensher et al., 2001;Gautam et al., 2005; Haigh and Pfau, 2006; Liu, 2009; Lavelle et al., 2009; Ng and Feldman, 2011; Morin et al., 2011; Chen and Kao, 2012; Islam et al., 2012). While several authors (Shore \& Wayne, 1993; Tepper, 2004; Mena, 2015; Rauf, 2016; Traiyotee et al., 2019) concluded that a positive and negative relationship between organizational citizenship behavior and organizational commitment as well different consequences of organizational citizenship behavior on organizational commitment were reported. 


\subsection{Organizational Citizenship Behavior as Mediator Variable in Organizational Behavior Literature}

Different researchers performed studies to test the mediation effect of organizational citizenship behavior on different aspects. A literature review by Harikaran and Thevanes (2018; p.26) to test the relationships among worklife balance, organizational citizenship behavior, and organizational performance, stated that "most studies neglect the mediating role of organizational citizenship behavior in the relationship between work-life balance and organizational performance", and concluded that, their review suggests the presence of positive relationships among the reviewed concepts, and that further their review tested the relationship of work-life balance, organizational performance, and organizational citizenship behavior and concluded that organizational citizenship behavior mediates the relationship between work-life balance and organizational performance. A study by Sugianingrat et al. (2019) was they test the mediation effect of organizational citizenship behavior on employee engagement dimensions on employee performance in a non-star hotel in Bali, Indonesia one of the world's tourist destinations. The study supported 150 respondents who are an employee at that hotel, and the concluded that organizational citizenship behavior was able to partially mediate the relationship. Andrew and León-Cázares (2015; p.73) suggested that organizational behavior may have a little effect on organizational effectiveness, and "argued that organizational citizenship behavior plays a mediator role between leadership styles, public service motivation and perceived organizational performance". In their study "Mediating Effects of Organizational Citizenship Behavior on Organizational Performance: Empirical Analysis of Public Employees" conducted in Mexico, the study results concluded that the empirical analysis shows that organizational citizenship behavior performs a mediator role between public service motivation and public organization performance. Another study by Islam et al. (2012) investigated the mediating role of organizational citizenship behavior between organizational learning culture and knowledge sharing in Malaysia, the study tested data of 402 employees results in a greater indirect impact of organizational learning culture on knowledge sharing via organizational citizenship behavior, and that organizational citizenship behavior performs as a mediator between the variables in this relationship. Other studies that confirmed the mediation role of citizenship behavior; Ariffin (2014) also confirmed a mediation role of citizenship behavior between organizational identity and organizational employer branding, and Kesen (2016) between organizational identification and individual creativity.

Additional to those studies, few studies were found that test the mediation effect of organizational citizenship behavior on the relationship between different variables including transformational leadership style and organizational commitment were found; the first study by Rita et al. (2018) the study examined the relationship between five variables; transformational leadership, organizational commitment, motivation, organizational citizenship behavior, and employee performance and test the moderation effect of organizational citizenship behavior. The study was performed at the district secretariat in Pupua province in Indonesia. The result of the study confirms that the moderation role of organizational citizenship behavior doesn't significantly affect the relationship between organizational commitment, transformational leadership, work motivation, and employee performance, however, the organizational citizenship behavior plays a mediator role and can strengthen the effect of job satisfaction and organizational commitment on organizational performance. A recent study by Traiyotee et al. (2019) with the focus target population of 4,088 employees of pt gas station in the northeast, Thailand. The study tests the significant influence of organizational citizenship behavior on organizational commitment and the mediation role of organizational citizenship behavior in the relationship between quality work-life and organizational commitment and concluded that organizational citizenship behavior statistically has a significant positive influence on organizational commitment, that organizational citizenship behavior performs as a mediator in the relationship between quality work-life and organizational commitment.

\subsection{Research Framework and Hypothesis}

Figure 1 depicts the research framework of the study between leadership styles, organizational citizenship behavior, and organizational commitment. Moreover, the study's hypotheses were listed below;

$H_{1}$ : Leadership has a positive effect on organizational commitment.

$\mathrm{H}_{2}$ : Leadership has a positive effect on organizational citizenship behavior.

$H_{3}$ : Organizational citizenship behavior has a positive effect on organizational commitment.

$\mathrm{H}_{4}$ : Organizational citizenship behavior has mediation between leadership and organizational commitment. 


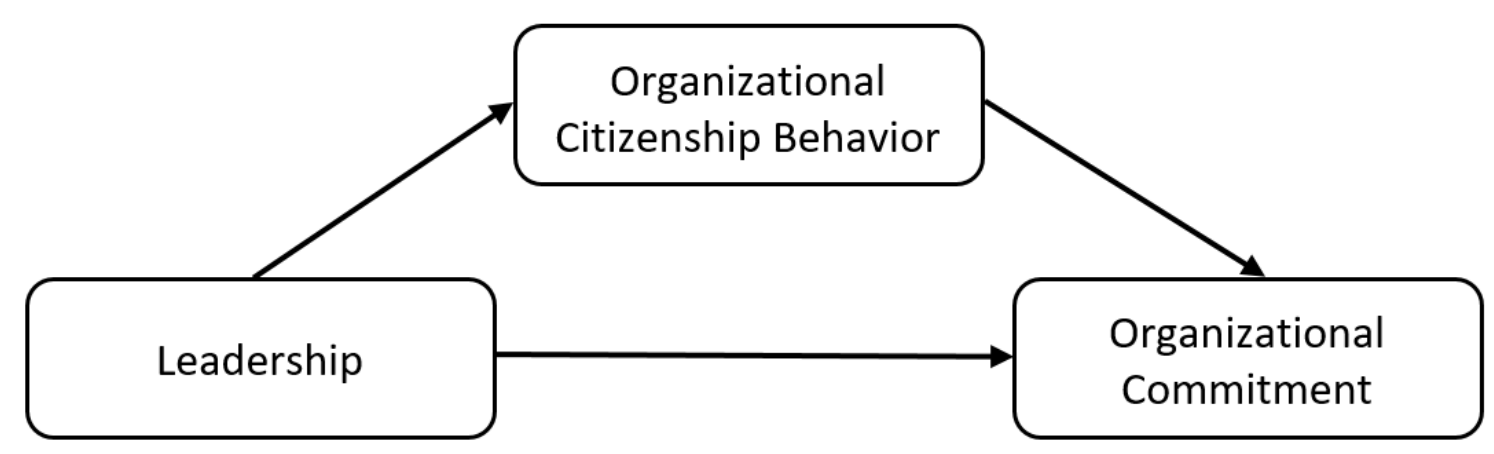

Figure 1- Research Framework

\section{Research Method \\ 3.1 Research Design}

This study involves leaders working in both the public and private sectors in the Kingdom of Bahrain. The study targets a population of employees working at different managerial levels in the private and public sectors. The research data was collected using a questionnaire. A total of 1,000 online surveys were distributed to respondents by the author. The introduction to the questionnaire explains the purpose of the research. Confidentiality was guaranteed to the participants. The total number of surveys collected by participants was 333 from the sample frame. Data were entered and coded in Excel. Table 1 depicts the respondent's profiles

\section{Table 1 Respondent's Profile}

\begin{tabular}{|l|l|l|l|}
\hline Demographic variable / groups & $\mathbf{n}$ & \% \\
\hline \multirow{3}{*}{ Gender } & Male & 202 & 60.7 \\
\cline { 2 - 4 } & Female & 131 & 39.3 \\
\hline \multirow{3}{*}{ Working Sector } & Private Sector & 152 & 45.6 \\
\cline { 2 - 4 } & Public Sector & 181 & 54.4 \\
\hline
\end{tabular}

\subsection{Measure}

To explore the role of organizational citizenship behavior as a mediator to the relationship between leadership and organizational commitment, the respondents were asked to answer a survey questionnaire that is consists of 72 questions divided into three parts, each part of the questionnaire represents a different instrument. Leadershipwas measured through Multifactor Leadership Questionnaire (MLQ 5X-Short version), the organizational commitment was measured through the revised 1993 Three-Component Model (TCM) Employee Commitment Survey by Meyer, Allen, and Smith (1993), and organizational citizenship behavior was measured by Podsakoff et al. (1990) OCBS. The questionnaire used a 5-point Likert scale (where were used for expressing 1-Strongly Disagreed and 5Strongly Agree). A pilot study was conducted on 30 participants from both the public and private sectors in the Kingdom of Bahrain to verify the validity and reliability study tool. Cronbach's alpha was used for every variable as depicted in Table 2. The reliability analysis has given the variable factors of leadership, organizational commitment, and organizational citizenship behavior with the Cronbach's alpha of 0.761, 0.810, and 0.802, subsequently. Thus, the tools used for the study are reliable based on the above values.

\section{Table 2 Cronbach's Alpha}

\begin{tabular}{|l|l|l|l|}
\hline Variables & No of Items & Cronbach's Alpha & Reliability Indication \\
\hline Leadership & 36 & 0.761 & Acceptable \\
\hline Organizational Commitment & 18 & 0.810 & Good \\
\hline Organizational Citizenship Behavior & 24 & 0.802 & Good \\
\hline
\end{tabular}

\section{Data Analysis and Results \\ 4.1 Correlation Analysis}

Table 3 depicts a correlation analysis of leadership styles, organizational commitment, and organizational citizenship behavior. 
Participants indicated that leadership had a significant relationship with organizational commitment $(r=0.239)$, and a significant relationship with organizational citizenship behavior $(\mathrm{r}=0.354)$. Meanwhile, participants indicated that organizational citizenship behavior had a significant relationship with organizational commitment $(\mathrm{r}=0.425)$.

Table 3 Correlation Coefficients

\begin{tabular}{|l|l|l|l|l|}
\hline & & 1 & 2 & 3 \\
\hline 1 & Leadership & 1 & $0.239 * *$ & $0.354 * *$ \\
\hline 2 & Organizational Commitment & & 1 & $0.425 * *$ \\
\hline 3 & Organizational Citizenship Behavior & & & 1 \\
\hline
\end{tabular}

Note: $* \mathrm{p}<.05 * * \mathrm{p}<.01$.

\subsection{Regression Analysis}

Table 4 depicts the simple regression analysis that was conducted on leadership toward organizational commitment, leadership toward organizational citizenship behavior, and organizational citizenship behavior toward organizational commitment. Participants are found to be a significant predictor of organizational commitment $(\mathrm{p}<0.000)$. As presented, first, leadership accounts for $5.7 \%$ of the variation in organizational commitment. The calculated $\mathrm{F}$ of 20.085 is significant at an alpha $<0.000$. The positive beta of 0.239 indicates that leadership has a significant positive effect on organizational commitment. Second, leadership accounts for $12.5 \%$ of the variation in organizational citizenship behavior. The calculated F of 47.349 is significant at an alpha $<0.000$. The positive beta of 0.354 indicates that leadership has a significant positive effect on organizational citizenship behavior. Third, organizational citizenship behavior accounts for $18.1 \%$ of the variation in organizational commitment. The calculated $\mathrm{F}$ of 72.922 is significant at an alpha $<0.000$. The positive beta of 0.425 indicates that organizational citizenship behavior has a significant positive effect on organizational commitment.

This indicates that there is significant statistical evidence for the positive relation relationship between leadership and organizational commitment, leadership and organizational commitment, and organizational citizenship behavior and organizational commitment.

Table 4 Simple Regression

\begin{tabular}{|l|l|l|l|l|l|l|}
\hline \multirow{2}{*}{ Factor } & \multicolumn{2}{|l|}{ LD and OC } & \multicolumn{2}{l|}{ LD and OCB } & \multicolumn{2}{l|}{ OCB and OC } \\
\cline { 2 - 6 } & Std. Beta & Sig. & Std. Beta & Sig. & Std. Beta & Sig. \\
\hline Leadership & 0.239 & 0.000 & 0.354 & 0.000 & 0.425 & 0.000 \\
\hline $\mathrm{R}^{2}$ & 0.057 & 0.125 & & 0.181 & 0.178 \\
Adjusted $\mathrm{R}^{2}$ & 0.054 & 0.123 & & 0.417 & \\
Std. Error & 0.447 & 0.259 & & 72.922 \\
F Statistics & 20.085 & 47.349 & & 0.000 & \\
Sig. & 0.000 & 0.000 & & & \\
\hline
\end{tabular}

LD (Leadership), OC (Organizational Commitment), OCB (Organizational Citizenship Behavior

\subsection{Mediation analysis}

To test Hypothesis $4\left(\mathrm{H}_{4}\right.$ : Organizational citizenship behavior has mediation between leadership and organizational commitment), the mediation analysis was done using Baron and Kenny's (1986) approach with the use of multiple regression analysis (Model 2). The mediation analysis of Baron and Kenny (1986) has 4 steps as below:

Step 1 is a simple regression analysis between leadership style and organizational commitment.

Table 5 Regression Analysis between Leadership and Organizational Commitment

\begin{tabular}{|l|l|l|}
\hline \multirow{2}{*}{$\begin{array}{l}\text { Leadership } \\
\text { (Model 1) }\end{array}$} & \multicolumn{2}{|c|}{ Organizational Commitment } \\
\cline { 2 - 3 } & 0.418 & Sig. \\
\hline $\mathrm{R}$ & 0.239 & 0.000 \\
\hline $\mathrm{R}^{2}$ & 0.057 \\
\hline Std. Error & 0.447 \\
\hline Sig. $F$ & 0.00 \\
\hline
\end{tabular}

Table 5depicts the first step of mediation analysis,an unstandardized regression weight of 0.418 for leadership in predicting organizational commitment. Thus, $\mathrm{c}=0.418$. The standard error was 0.093, which give $\mathrm{t}=0.418 / 0.093=4.495(\mathrm{df}=331, \mathrm{p}=0.000)$. 
Furthermore, the set of data indicated that as the increase of leadership by one unit, the predicted value on organizational commitment increased by 0.418 . Thus, the result had satisfied the first condition necessary for mediation.

Step 2 is a simple regression analysis between leadership style and organizational citizenship behavior.

Table 6 Regression Analysis between Leadership and Organizational Citizenship Behavior

\begin{tabular}{|c|c|c|}
\hline \multirow[t]{3}{*}{ Leadership } & \multicolumn{2}{|c|}{ Organizational Citizenship Behavior } \\
\hline & $\bar{\beta}$ & Sig. \\
\hline & 0.372 & 0.000 \\
\hline $\mathrm{R}$ & \multicolumn{2}{|l|}{0.354} \\
\hline $\mathrm{R}^{2}$ & \multicolumn{2}{|l|}{0.125} \\
\hline Std. Error & \multicolumn{2}{|l|}{0.259} \\
\hline Sig. $F$ & \multicolumn{2}{|l|}{0.000} \\
\hline
\end{tabular}

Table 6depicts the second step of mediation analysis, an unstandardized regression weight of 0.372 for leadership in predicting organizational citizenship behavior. Thus, $a=0.372$. The standard error was 0.054 , which gives $\mathrm{t}=0.372 / 0.054=6.889(\mathrm{df}=331, \mathrm{p}=0.000)$. Furthermore, the set of data indicated that as the increase of leadership by one unit, the predicted value on organizational citizenship behavior increased by 0.372 . Thus, the result had satisfied the second condition necessary for mediation

Step 3 is a simple regression analysis between organizational citizenship behavior and organizational commitment.

Table 7 Regression Analysis between Organizational Citizenship Behavior and Organizational Commitment

\begin{tabular}{|c|c|c|}
\hline \multirow{3}{*}{ Organizational Citizenship Behavior } & \multicolumn{2}{|c|}{ Organizational Commitment } \\
\hline & $\bar{\beta}$ & Sig. \\
\hline & 0.706 & 0.000 \\
\hline $\mathrm{R}$ & 0.425 & \\
\hline $\mathrm{R}^{2}$ & 0.181 & \\
\hline Std. Error & 0.417 & \\
\hline Sig. $F$ & 0.000 & \\
\hline
\end{tabular}

Table 7depicts the third step of mediation analysis, an unstandardized regression weight of 0.706 for leadership in predicting organizational citizenship behavior. Thus, $b=0.706$. The standard error was 0.083 , which gives $\mathrm{t}=0.706 / 0.083=8.506 \quad(\mathrm{df}=331, \mathrm{p}=0.000)$. Furthermore, the set of data indicated that as the increase of organizational citizenship behavior by one unit, the predicted value on organizational citizenship behavior increased by 0.706 . Thus, the result had satisfied the third condition necessary for mediation.

Step 4 is the multiple regression analysis between leadership style and organizational commitment with the mediation of organizational citizenship behavior.

Table 8 Multiple Regression Analysis between Leadership and Organizational Commitment with Mediation of Organizational Citizenship Behavior

\begin{tabular}{|c|c|c|}
\hline \multirow{2}{*}{ Model 2} & \multicolumn{2}{|c|}{ Organizational Commitment } \\
\hline & $\beta$ & Sig. \\
\hline Leadership & 0.177 & 0.056 \\
\hline Organizational Citizenship Behavior & 0.647 & 0.000 \\
\hline $\mathrm{R}$ & \multicolumn{2}{|l|}{0.435} \\
\hline R Square & \multicolumn{2}{|l|}{0.190} \\
\hline Std. Error & \multicolumn{2}{|l|}{0.415} \\
\hline Sig. $F$ & \multicolumn{2}{|l|}{0.000} \\
\hline
\end{tabular}

Table 8depicts the fourth step Baron and Kenny (1986) and is known as Model 2 (c'). Model 2 in an unstandardized regression weight of 0.177 for leadership in predicting organizational commitment when controlling organizational citizenship behavior. Thus, $c^{\prime}=0.177$. The standard error was 0.093 , which give $t=0.117 / 0.093=1.258(\mathrm{df}=331$, $\mathrm{p}<0.05$ ). This coefficient was not statistically significantly different from zero; however, it had not shown that the coefficient is equal to zero. 
Furthermore, with the increased leadership by one unit, while holding constant the effects of organizational citizenship behavior, the predicted value on organizational commitment increased by 0.177 units. However, this difference was not statistically significant. The result had not satisfied the fourth condition necessary for complete mediation. Thus, the result had a partial mediation.

In conclusion, the described findings indicate that there is a significant relationship between leadershipand organizational commitment, leadership and organizational citizenship behavior, organizational citizenship behaviors, and organizational commitment. The study established a partial mediation of organizational citizenship behavior to the relationship between leadership and organizational commitment.

In summary, the participants indicated that the hypotheses $\mathrm{H}_{1}, \mathrm{H}_{2}$, and $\mathrm{H}_{3}$, were supported, and hypothesis $\mathrm{H}_{4}$ results in partial mediation. Table 9 depicts the results of the research analysis.

Table 9 The result of research analysis

\begin{tabular}{|l|l|}
\hline Hypothesis & \\
\hline $\mathrm{H}_{1}$ : Leadership has a positive effect on organizational commitment & Supported \\
\hline $\mathrm{H}_{2}$ : Leadership has a positive effect on organizational citizenship behavior & Supported \\
\hline $\mathrm{H}_{3}$ : Organizational citizenship behavior has a positive effect on organizational commitment & Supported \\
\hline $\begin{array}{l}\mathrm{H}_{4}: \text { Leadership has a positive effect on organizational commitment with the mediation of } \\
\text { organizational citizenship behavior }\end{array}$ & Partial Mediation \\
\hline
\end{tabular}

\section{Discussion}

This study contributes to the existing literature since the majority of hypotheses have been supported. Besides, the hypotheses agree with the results of the highlighted previous studies. Most importantly, the study followed the instructions highlighted by Baron and Kenny (1986) where the three following regression equations were tested:

The first regression equation is about regressing the mediator (Organizational citizenship Behavior) on the independent variable (Leadership).

The second regression equation is regressing the dependent variable (Organizational Commitment) on the independent variable (Leadership).

The third regression equation is regressing the dependent variable (Organizational Commitment) on both the independent variable (Leadership) and the mediator (Organizational citizenship Behavior).

The study confirmed a partial mediation relationship between leadership, the results reached are worth to be considered valuable to organizations as they might be helpful to consider such a mediation relationship when planning to increase the level of commitment in their succession plans, recruiting plan, training plan, and organization values.

\section{Conclusion}

This study explores the mediation effect of organizational citizenship behavior on the relationship between leadership and organizational commitment. Also, it intended to find the relationship between leadership and organizational commitment. The study explored that, leaderships positively affect organizational commitment and organizational citizenship behavior, organizational citizenship behavior positively affects organizational commitment, and confirmed the partial mediating of organizational citizenship behavior.

In conclusion, the result of the mediation of organizational citizenship behavior on the relationship between leadership and organizational commitment is in line with previous studies' results (Rita et al., 2018; Traiyotee et al., 2019).

\section{References}

Andrew, S. A., \& León-Cázares, F. (2015). Mediating Effects of Organizational Citizenship Behavior on Organizational Performance: Empirical Analysis of Public Employees in Guadalajara, Mexico. EconQuantum, 12(2), 71-92.

Ariffin, H. F. (2014). Measuring organizational commitment through its relationship with organizational identity, organizational citizenship behaviour, and organizational employer branding (Doctoral dissertation, University Malaya).

Arnold, J. A., Arad, S., Rhoades, J. A., \&Drasgow, F. (2001). The Empowering Leadership Questionnaire: The Construction and Validation of A New Scale for Measuring Leader Behaviors. Journal of Organizational Behavior, 21(3), 249-269.

Aydoğan, İ. (2010). Örgütselvatandaşlıkdavranışı. H. B. MemduoğluveKürşad Yılmaz. (Editörler). Yönetimdeyeniyaklaşımlar. Ankara PegemAkademi, 292-320. 
Baron, R. M., \& Kenny, D. A. (1986). The moderator-mediator variable distinction in social psychological research: Conceptual, strategic, and statistical considerations. Journal of Personality and Social Psychology, 51, 1173-1182.

Blakely, Gerald L., Martha C. Andrews, \& Robert H. Moorman. (2005). The moderating effects of equity sensitivity on the relationship between organizational justice and organizational citizenship behaviors. Journal of Business and Psychology 20, 259-273.

Bogler, R., \&Somech, A. (2004). Influence of teacher empowerment on teachers' organizational commitment, professional commitment, and organizational citizenship behavior in schools. Teaching and teacher education, 20(3), 277-289.

Bolat, O. İ., \&Bolat, T. (2008). OTEL İŞLETMELERINNDE ÖRGÜTSEL BAĞLILIK VE ÖRGÜTSEL VATANDAŞLIK DAVRANIŞI İLIŞSİSİ. BalıkesirÜniversitesiSosyalBilimlerEnstitüsüDergisi, 11(19), 75-94.

Bolden, R., Gosling, J., Marturano, A., \& Dennison, P. (2003). A review of leadership theory and competency frameworks. Centre for leadership studies, University of Exeter.

Chen, C. H. V., \& Kao, R. H. (2012). Work values and service-oriented organizational citizenship behaviors: The mediation of psychological contract and professional commitment: A case of students in Taiwan Police College. Social Indicators Research, 107(1), 149-169.

Chen. L.Y. (2002). An Examination of the Relationship between Leadership Behavior and Organizational Commitment at Steel Companies. The Journal of Applied Management and Entrepreneurship, 7(2): 122142.

Cohen, J. (1988). Statistical Power Analysis for the Behavioral Sciences (2nd ed.). Hillsdale, NJ: Lawrence Erlbaum Associates, Publishers.

Duchon, D., Green, S. G., \& Taber, T. D. (1986). Vertical dyad linkage: A longitudinal assessment of antecedents, measures, and consequences. Journal of applied psychology, 71(1), 56-60.

Ehrhart, M. G., \&Naumann, S. E. (2004). Organizational citizenship behavior in workgroups: a group norms approach. Journal of applied psychology, 89(6), 960-977.

Ensher, E. A., Grant- Vallone, E. J., \& Donaldson, S. I. (2001). Effects of perceived discrimination on job satisfaction, organizational commitment, organizational citizenship behavior, and grievances. Human resource development quarterly, 12(1), 53-72.

Erkutlu, H. (2008). The impact of transformational leadership on organizational and leadership effectiveness: The Turkish case. Journal of management development, 27(7), 708-726.

Feather, N. T., \&Rauter, K. A. (2004). Organizational citizenship behaviours in relation to job status, job insecurity, organizational commitment and identification, job satisfaction, and work values. Journal of occupational and organizational psychology, 77(1), 81-94.

Gautam, T., van Dick, R., Wagner, U., Upadhyay, N., \& Davis, A. J. (2005). Organizational citizenship behavior and organizational commitment in Nepal. Asian Journal of Social Psychology, 8, 305-314.

Graen, G., Novak, M. A., \&Sommerkamp, P. (1982). The effects of leader-member exchange and job design on productivity and satisfaction: Testing a dual attachment model. Organizational behavior and human performance, 30(1), 109-131.

Graen, G.B. (1976). Role making processes within complex organizations. In: M.D. Dunnette (Ed.), Handbook of Industrial and Organizational Psychology (pp. 1201-1245). Chicago: Rand-McNally

Haigh, M. M., \&Pfau, M. (2006). Bolstering organizational identity, commitment, and citizenship behaviors through the process of inoculation. International Journal of Organizational Analysis, 14(4), 295-316.

Harikaran, S. \&Thevanes, N. (2018). The relationship between work-life balance, organizational citizenship behavior, and organizational performance: a review of the literature. Journal of Business and Management, 20(8): 25-31.

Horner, M. (1997). Leadership theory: past, present, and future. Team Performance Management: An International Journal, 3(4), 270-287.

Islam, T., Anwar, F., Khan, S. U., Rasli, A., Ahmad, U. N., \& Ahmed, I. (2012). Investigating the mediating role of organizational citizenship behavior between organizational learning culture and knowledge. World Applied Sciences Journal, 19(6), 795-799.

Ismail, A., Mohamed, H. A. B., Sulaiman, A. Z., Mohamad, M. H., \& Yusuf, M. H. (2011). An empirical study of the relationship between transformational leadership, empowerment, and organizational commitment. Business and Economics Research Journal, 2(1), 89-107.

Jogulu, U. D., \& Wood, G. J. (2008). A cross-cultural study into peer evaluations of women's leadership effectiveness. Leadership \& Organization Development Journal, 29(7), 600-616.

Johnson, R. B., \&Onwuegbuzie, A. J. (2004). Mixed methods research: A research paradigm whose time has come. Educational researcher, 33(7), 14-26.

Kesen, M. (2016). Linking organizational identification with individual creativity: organizational citizenship behavior as a mediator. Journal of Yasar University, 11(41), 56-66. 
Kim, H. (2012). Transformational leadership and organizational citizenship behavior in the public sector in South Korea: the mediating role of affective commitment. Local Government Studies, 38(6), 867-892.

Lavelle, J. J., Brockner, J., Konovsky, M. A., Price, K. H., Henley, A. B., Taneja, A., \&Vinekar, V. (2009). Commitment, procedural fairness, and organizational citizenship behavior: A multifoci analysis. Journal of Organizational Behavior: The International Journal of Industrial, Occupational and Organizational Psychology and Behavior, 30(3), 337-357.

Lee, J. (2005). Effects of leadership and leader-member exchange on commitment. Leadership \& organization development journal, 26(8), 655-672.

LePine, J. A., Erez, A., \& Johnson, D. E. (2002). The nature and dimensionality of organizational citizenship behavior: a critical review and meta-analysis. Journal of applied psychology, 87(1), 52.

Liden, R. C., Wayne, S. J., \& Stilwell, D. (1993). A longitudinal study on the early development of leader-member exchanges. Journal of applied psychology, 78(4), 662.

Limsila, K., \&Oginlana, S.O. (2008). Performance and Leadership Outcome Correlates of Leadership Styles and Subordinate Commitment. Engineering, Construction and Architectural Management, 15(2), 164-184.

Liu, Y. (2009). Perceived organizational support and expatriate organizational citizenship behavior: The mediating role of affective commitment towards the parent company. Personnel Review, 38(3), 307-319.

Lo, M. C., Ramayah, T., \& Min, H. W. (2009). Leadership styles and organizational commitment: a test on Malaysia manufacturing industry. African Journal of Marketing Management, 1(6), 133-139.

Mathieu, J., \&Zajac, D. (1990). A review and meta-analysis of the antecedents, correlates, and consequences of organizational commitment. Psychological Bulletin, 108, 171-194.

McGuire, E., \&Kennerly, S. M. (2006). Nurse managers as transformational and transactional leaders. Nursing Economics, 24(4), 179.

Mena, L. (2015). Organizational commitment and organizational citizenship behavior: trend and relationship. Intercontinental journal of human resource research review, 3(9), 18-25.

Mercan, M. (2006). Öğretmenlerdeörgütselbağl1lıkörgütselyabancılaşmaveörgütselvatandaşlık (Master's thesis, AfyonKocatepeÜniversite, SosyalBilimlerEnstitüsü).

Meyer, J. P., Allen, N. J., \& Smith, C. A. (1993). Commitment to organizations and occupations: Extension and test of a three-component conceptualization. Journal of applied psychology, 78(4), 538.

Morin, A. J., Morizot, J., Boudrias, J. S., \&Madore, I. (2011). A multifoci person-centered perspective on workplace affective commitment: A latent profile/factor mixture analysis. Organizational Research Methods, 14(1), 58-90.

Mosadeghrad, A. M., \&Ferdosi, M. (2013). Leadership, job satisfaction and organizational commitment in healthcare sector: Proposing and testing a model. Materia socio-medica, 25(2), 121.

Mowday, R. T., Porter, L. W., \& Steers, R. M. (1982). Employee-organization linkages: The psychology of commitment, absenteeism, and turnover. New York, NY: Academic Press.

Ng, T. W., \& Feldman, D. C. (2011). Affective organizational commitment and citizenship behavior: Linear and non-linear moderating effects of organizational tenure. Journal of Vocational Behavior, 79(2), 528-537.

Nguni, S., Sleegers, P., \&Denessen, E. (2006). Transformational and transactional leadership effects on teachers' job satisfaction, organizational commitment, and organizational citizenship behavior in primary schools: The Tanzanian case. School effectiveness and school improvement, 17(2), 145-177.

Nystrom, P. C. (1990). Vertical exchanges and organizational commitments of American business managers. Group \& Organization Studies, 15(3), 296-312.

Podsakoff, P. M., \&MacKenzie, S. B. (1997). Impact of organizational citizenship behavior on organizational performance: A review and suggestion for future research. Human performance, 10(2), 133-151.

Podsakoff, P. M., MacKenzie, S. B., Moorman, R. H., \& Fetter, R. (1990). Transformational leader behaviors and their effects on followers' trust in leader, satisfaction, and organizational citizenship behaviors. The leadership quarterly, 1(2), 107-142.

Podsakoff, P. M., MacKenzie, S. B., Paine, J. B., \&Bachrach, D. G. (2000). Organizational citizenship behaviors: A critical review of the theoretical and empirical literature and suggestions for future research. Journal of Management, 26(3), 513-563.

Rauf, F. H. A. (2016). Two sides of the same coin: harmful or helpful? A critical review of the consequences of organizational citizenship behavior. International journal of business and management review, 4(2), 60-77.

Rita, M., RandaPayangan, O., Rante, Y., Tuhumena, R., \&Erari, A. (2018). Moderating effect of organizational citizenship behavior on the effect of organizational commitment, transformational leadership and work motivation on employee performance. International Journal of Law and Management, 60(4), 953-964.

Schnake, M. (1991). Organizational citizenship: A review, proposed model, and research agenda. Human Relations, 44(7), 735-759.

Sekaran, U. (2013). Research Methods for Business: A Skill Building Approach. (4th Ed.), New York, NY: John Wiley \& Sons, Inc. 
Shore, L. M., \& Wayne, S. J. (1993). Commitment and employee behavior: Comparison of affective commitment and continuance commitment with perceived organizational support. Journal of applied psychology, 78(5), 774-780.

Sugianingrat, D. A. P. W., Yasa, N. N. K., Sintaasih, D. K., \&Subudi, M. (2019). Organizational citizenship behavior as mediation effect of employee engagement dimensions on employee performance (study in non-star hotel, Bali, Indonesia). Journal of Engineering and Applied Sciences, 14(7), 2146-2151.

Tansky, J. W. (1993). Justice and organizational citizenship behavior: What is the relationship?.Employee Responsibilities and Rights Journal, 6(3), 195-207.

Tepper, B. J., Duffy, M. K., Hoobler, J., \& Ensley, M. D. (2004). Moderators of the relationships between coworkers' organizational citizenship behavior and fellow employees' attitudes. Journal of Applied Psychology, 89(3), 455-465.

Traiyotee, P., Taeporamaysamai, P., \&Saksamrit, N. (2019). Quality of work life affecting on organizational commitment through organizational citizenship behaviour: a case study of PT gas service stations employees in the northeast, Thailand. The 2019 International Academic Research Conference in Vienna, 267-272.

Tremblay, M. A. (2010). Fairness perceptions and trust as mediators on the relationship between leadership style, unit commitment, and turnover intentions of Canadian forces personnel. Military Psychology, 22(4), 510523.

Vecchio, R. P., \&Gobdel, B. C. (1984). The vertical dyad linkage model of leadership: Problems and prospects. Organizational behavior and human performance, 34(1), 5-20.

Veličkovska, I. (2017). Organizational citizenship behavior-definition, determinants and effects. Engineering Management, 3(1), 40-51.

Zayas-Ortiz, M., Rosario, E., Marquez, E., \& Colón Gruñeiro, P. (2015). Relationship between organizational commitments and organizational citizenship behaviour in a sample of private banking employees. International Journal of Sociology and Social Policy, 35(1/2), 91-106. 